\title{
Improved the ability to read the Quran for slow learner students in Yogyakarta: Single case research approach
}

\author{
Hanif Cahyo Adi Kistoro a,1,* \\ a Universitas Ahmad Dahlan, Jl. Ringroad Selatan, Kragilan, Tamanan, Banguntapan, Bantul, Yogyakarta, 55191, Indonesia \\ ${ }^{1}$ hanif.kistoro@pai.uad.ac.id \\ * corresponding author
}

\section{ARTICLE INFO}

\section{Article History}

Received: 04 of January, 2020

Revised: 26 of March, 2020 Accepted: 21 of April, 2021

Keyword: Ability to read AlQuran, Slow learner, makharijul huruf, Tajwid, Tartil

Kata Kunci: Kemampuan membaca Al-Quran, slow learner, makharijul huruf, Tajwid, Tartil

\begin{abstract}
This study aims to improve the ability of slow learner students in reading the Quran. This type of research is a single case or single-case research with the ABABA intervention model. The research subjects were student at Muhammadiyah Junior High School Kulonprogo Yogyakarta. The sampling technique used purposive sampling. The data were collected using an assessment sheet instrument based on practical tests, observation sheets, and interview protocols. The assessment data were analyzed using descriptive statistics in the form of scoring based on the results of the test or treatment given based on each stage. The enhancement of the subject's ability was carried out by the AIR (Auditory Intellectually Repetition) method which is has the banaficial category because in a short period it could give results even though it was not optimal. The AIR method itself is a learning model with assignments that emphasize understanding listening to the material with a practice that is carried out repeatedly to gain deep understanding. While the results of observations and interviews are described in a narrative. The results of the study concluded that there was an increase in the students' ability to read the Quran according to the observed aspects, namely the increase in the ability of the Makhorijul Huruf, Tawjid, and Tartil after attending the training. The ability of the subject's Makhorijul Huruf increased $66.6 \%$ than before the intervention, they are from 30 to 50 as result. Tajwid ability increased $33.3 \%$ from 30 to 40 as result, and Tartil ability increased by $14.28 \%$ from 35 to 40 as resultr, and Tartib experienced an increase of $100 \%$ from 25 to 50 . These results indicate the increase in students' ability to read the Quran in the quite good category.
\end{abstract}

\section{ABSTRAK}

Penelitian ini betujuan untuk meningkatkan kemampuan siswa slow learner dalam membaca al quran. Jenis penelitian adalah kasus tunggal dengan model intervensi ABABA. Subyek penelitian berjumlah 1 orang siswa Sekolah Menengah Pertama Muhammadiyah di Kulonprogo Yogyakarta. Teknik sampling menggunakan purposive sampling. Pengambilan data menggunakan instrument lembar penilaian berdasarkan tes praktik, lembar observasi dan protokol wawancara. Data penilaian dianalisis dengan statistik deskriptif dalam bentuk pemberian skor berdasarkan hasil tes atau treatment yang diberikan berdasarkan masing-masing tahapan. Peningkatan kemampuan subyek dilakukan dengan metode AIR, yaitu Auditory Intellectually Repetition yang secara pelaksanaan termasuk kategori efektif karena dengan waktu yang pendek dapat memberikan hasil kemampuan meskipun belum maksimal. Metode AIR sendiri merupakan model pembelajaran dengan pemberian tugas yang menekankan pada pemahaman mendengar materi dengan praktek yang dilakukan secara berulangulang untuk mendapatkan pemahaman mendalam. Sedangkan hasil observasi dan wawancara di deskripsikan secara naratif. Hasil penelitian disimpulkan bahwa ada peningkatan kemampuan siswa dalam membaca al-Quran sesuai aspek yang diamati yaitu pada peningkatan kemampuan Makhorijul Huruf, Tawjid dan Tartil setelah mengikuti pelatihan. Kemampuan Makhorijul Huruf subyek meningkat $66,6 \%$ dari awal sebelum dilakukan intervensi yaitu 30 menjadi 50 . Kemampuan Tajwid meningkat 33,3\% dari 30 menjadi 40, dan kemampuan tartil meningkat $14,28 \%$ dari 35 menjadi 40 dan tertib mengalami kenaikan $100 \%$ dari 25 menjadi 50. Hasil ini menunjukan kenaikan kemampuan siswa dalam membaca al quran masuk pada kategori baik.

This is an open access article under the CC-BY-SA license.

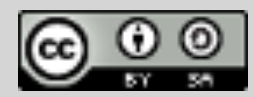




\section{Introduction}

Islam teaches that education is an absolute necessity for humans. education is a learning process that starts with the ability to read, write and reason logically [1]. Education in another sense is a conscious effort made by educators to guide, educate, train, direct students to realize the expected educational goals [2]. Education can also be interpreted as a process of preparing the younger generation to carry out their daily lives and to fulfill their life goals more effectively and efficiently [3]. The existence of education will be able to develop existing abilities in students in realizing competencies in cognitive, affective, and psychomotor fields which will later be needed for themselves and society. The educational learning process is a key to the achievement and success of the goals of education. Learning is a form of the learning process that is built by educators to develop creative thinking that can improve students' thinking abilities and can increase their ability to construct new knowledge to increase good mastery of subject matter [4].

This need for education should automatically be provided for normal children or children with special needs. This is strengthened by the provisions that have been outlined in Law number 20 of 2003 concerning the National Education System. In chapter IV article 5 paragraph 1 it is stated that every citizen has the same right to obtain quality education [5]. In article 5, paragraph 2, which states that "citizens who have physical, mental, intellectual, emotional and social disabilities are entitled to special education based on the above law, it can be understood that all citizens, including students with special needs, also have the right to get an education.

However, what happened in the field was not as expected. There are many gaps in the learning process, especially for children with special needs. The existence of educational regulations regarding inclusive schools, where every school must accept children with special needs also raises problems. Schools that are not ready to accept children with special needs, on the one hand, must prepare teachers who have the competence to teach inclusive children [6]. The curriculum must also be adjusted so that young children can receive learning well. Schools must also prepare complete infrastructure and facilities. The existence of the above problems raises problems for schools. Not to mention that personally, other problems usually arise, namely the existence of bullying by normal students towards children with special needs [7].

The curriculum field also has its problems [8]. In inclusive schools, children with normal and special needs get the same curriculum [9]. This makes teachers have to have high creativity and innovation to keep providing material according to the existing curriculum. On the other hand, not all teachers have good competence to teach in an inclusive class [10]. In general, all children, whether normal or with special needs, must get character education, one of which is in the material of religious education [11]. Religious education as a compulsory subject in schools also has problems in its learning practices, especially children with special needs, such as slow learner / slow learner children, autism, Down syndrome, and others. Children with special needs have their types and characters in their learning interactions [12]. so they also need special treatment in the learning process.

Islamic religious education, which one of the goal is to strengthen religious aspects in the form of student attitudes and behavior, of course also has its problems. Religious education is needed by every individual not only for worship but also as a provision in life, especially about social relations in their environment. One of the materials in Islamic religious education is reading the Koran. Teaching al Quran is one of the obligations in developing children's potential in the field of religious education.

In the learning process, which includes religious education learning, of course, many factors will influence the success of this learning. Globally, the factors that affect student learning can be grouped into 3 types. First, internal factors, namely factors that come from within students, which are focused on the state or condition of the student's physical and spiritual. Second, external factors, namely factors that come from outside the students, which are focused on the environmental conditions around the students. Third, the learning approach factor, namely the type of student learning effort which includes the methods and strategies used by students to carry out learning activities from subject matter [13]. Educators must educate according to children's needs so that students can accept and respond to learning easily. Teachers must have creativity in delivering material in learning and have special skills in various methods and methods of delivery. 
This study will examine the ability to read the Koran for children with special needs who are categorized as slow learners / slow learners. Slow learner children are children who have a learning delay, where they have low learning achievement (below the average of children in general) either only in one subject or even all subjects, but the slow learner is not classified as a mentally retarded child [14].Slow learner children usually take longer than other students. Physically, slow learner children have no difference from other children [15]. But children's abilities like this will be seen during learning. The slower ability of their peers makes slow learner children need special educational services [16]. The need for special services for slow learner children in learning [17], is usually related to: 1) difficulty in understanding abstract concepts; 2) limited vocabulary skills; 3) low learning motivation; 4) longer in understanding the material; and 5) Requires repetition in material giving [18].

Teachers who teach students with special needs are required to have complete skills and knowledge abilities. By the provisions, four competencies must be possessed, namely teaching skills (pedagogic), professional abilities, personal abilities, and social abilities. All these competencies academically will help students understand the subject matter given. No exception for children with special needs. Not all of these abilities are possessed by teachers. This problem has an impact on the achievement of school targets and goals. The problem that arises is that there is a teacher strategy model in improving Islamic religious learning, especially in increasing the ability to read the Koran for slow learner children.

Realizing the importance of religious education, especially reading the Koran for slow learner children, this research will answer research questions about the strategy of improving reading the Koran like slow learner students. This study will also answer the obstacles and obstacles faced by teachers in implementing learning to improve the ability to read the Koran for slow learner children. The focus of this research will explain the process of implementing Islamic religious learning specifically for reading the Koran. The implementation of logging starts from the preparation, implementation, and evaluation of the learning that has been done.

\section{THEORETICAL REVIEW}

\subsection{Understanding slow learner}

A Slow Learner is a child who has a lower intellectual level than normal children of his age, but slow learner children are not included as mentally retarded [19], because slow learners do not have a history of mental retardation, it's just that their intellectual abilities are slightly below normal children [20].

Slow Learners (slow learner) students are students who fail to learn at the same speed learned by the majority of other students [21]. He failed to learn, in an academic setting, what the teachers thought he should learn. Added by Featherstone [22] that slow learner children are children of the same age but have limitations in understanding, emotions, and attention.

From some of the opinions above, it can be concluded that slow learner children are children who have slightly lower intellectual potential than normal children of their age. The characteristics of slow learner children usually experience obstacles or delays in thinking (slow in thinking), respond to stimuli, adapt to the social environment, but are better than mentally retarded children and are slower than normal children [23]. So that in learning slow learner children must take longer to learn [24]. Besides that, special attention is also given to learning to develop its potential optimally.

\subsection{Ability to read Al Quran}

Islamic Religious Education is a conscious and planned effort to prepare students to recognize, understand, appreciate, and believe in Islamic teachings, coupled with demands to respect adherents of other religions about inter-religious harmony to create national unity and unity [25]. Or it could be explained that Islamic Religious Education is a conscious and planned effort in preparing students to know, understand, appreciate, believe in, pious, have a noble character, practice Islamic teachings from the main source of the holy books al-Qur'an and al-Hadith [26]. Through guidance activities, teaching exercises, and the use of experiences [27]. The Quran itself as a holy book means 
"perfect reading". This means that in reading the Quran the spelling of letters per letter is very important because it can affect the meaning and meaning [28].

Based on this understanding, according to the learning of reading Al-Quran, several things need to be considered in reading skills, namely the ability to read partially, according to the rules of recitation and the makhrojul letters.

The definition of tartil in general is reading slowly by paying attention to the recitation. By Ashshabuni, tartil is given the meaning of reading the Quran quietly slowly, and the letters [29]. With slow and clear reading, the person who hears it will be able to both understand and contemplate its meaning. Meanwhile, Al-Maraghi added that the meaning of tartil is to present the heart when reading, not just removing the letters from the throat by wrinkling the face, mouth, and singing rhythm [30].

By the above understanding, it can be concluded that the understanding of the ability to read the Qur'an in tartil is to read slowly with good reading, by the letter's makhrojul and make people who hear it happy and interested in the reading and its meaning. Another ability in reading the Quran is about the mahkrojul letter and its recitation. Tajweed is a way of reading the Quran properly and in an orderly manner according to its makhraj, short length, thickness, thinness, buzzing or not as well as the rhythm of the tone and the stop sign [28]. What is meant by makhraj is the place where the hijaiyah letters come out. So the ability of makhraj is the ability to pronounce hijaiyah letters according to their place of exit.

The ability requirements that students must have in learning the Quran require students to be able to do everything well. All of these activities are carried out in order and properly or in an orderly manner. Because with good ability to read the Quran, students are expected to be able to learn the reading and the content of the Qur'an is also better.

The problem that often arises in the field is that the ability to read the Quran is different from one child to another. No exception for children who are slow learners / slow learners. The existence of this problem is interesting for researchers to examine more deeply how the teacher's strategy in improving the ability of slow learner or slow learner students in reading the Qur'an before and after being given intervention or treatment.

\subsection{Al-Quran reading strategies for slow learner students}

Technically, slow learner children can be improved by special methods. As explained by Girish [31] that the academic function of children who learn slowly can improve significantly if they are given individual education. After going through the training program, most children have increased their potential, talents, and abilities to learn.

In this study, one of the learning strategies that are expected to be able to improve the ability of slow learner students in reading the Quran is to provide special intervention or treatment [32]. The intervention that will be provided by using the Auditory Intellectually Repetition (AIR) learning model method includes three aspects, they are: Auditory (hearing), Intellectually (thinking), and Repetition (repetition) individually [33]. is that slow learner students will be given learning with the drill method personally to find out their initial abilities as well as to improve students' abilities after receiving treatment or intervention. This intervention will only look at students' abilities in the ability of Makharijul Huruf, Tartil, Tajwid, and Tartib.

\section{Method}

\subsection{General Background}

This research is single case research. Single case research or SCR is a study that makes a research design in the form of intervention or treatment of subjects that effectively documents that improvements have occurred [34]. This research design is usually a case that occurs in individuals/singles whose subjects can occur in students, teachers, or even parents. SCR research is a study that allows using one subject by following the logic of experimental research types [35]. 
The intervention design used the ABABA design by Kratochwill's presentation that at least five points were observed [36]. Where A is pre-intervention / baseline 1, B is the first intervention, second $\mathrm{A}$ is baseline 2 , the second $\mathrm{B}$ is intervention 2 , and third $\mathrm{A}$ is the final condition [37].

The development of students' reading ability from the initial condition to the fifth condition was continuously observed and reported. The intervention intended in this study is to provide training for students who are research subjects. Students are explained the basic principles in the ability to read the Koran, namely, about mahkrojul letters, tawjid, tartil, and their order. This indicator of increase occurs when the intervention has been carried out.

One of the characteristics of single-case research is the use of interventions or the provision of stimulants to subjects. Stimulants are given using the AIR method, Auditory Intellectually Repetition (AIR). The AIR method is a learning model with assignments that emphasize listening comprehension in a repeated manner [38]. This repetition is expected to increase students' understanding. The task given is to practice reading the Koran repeatedly. Maulana added that the AIR learning model considers that a lesson will be effective if it considers three things, namely Auditory, Intellectual, and Repetition. Auditory means that the ear senses are used in learning by listening, speaking, presenting, arguing, expressing opinions, and responding [39]. Intellectual means that thinking skills need to be trained through training in reasoning, creating, solving problems, constructing, and implementing. Repetition means repetition is needed in learning so that understanding is deeper and broader, students need to be trained through solving questions, giving assignments or quizzes.

This AIR learning model is expected to be suitable to be applied in learning to read the Koran for slow learner students. This AIR learning model also aims to improve students' reasoning abilities. The Intellectual part of the AIR method which means the ability to think encourages students to slowly train to reason, create, solve problems, construct, and apply.

\subsection{Participants}

This AIR learning model is expected to be suitable to be applied in learning to read the Koran for slow learner students. This AIR learning model also aims to improve students' reasoning abilities. The Intellectual part of the AIR method which means the ability to think encourages students to slowly train to reason, create, solve problems, construct, and apply.

This Single Case Research was conducted at junior high schools based on religious schools in Yogyakarta which have implemented inclusive schools. The research was conducted for two months, namely September and October 2019. The subject of this study was a student with the initials M class XIII who is a student with the slow learner category. Selection of subjects using a purposive technique, where the criteria subject has been determined before, specifically students with the slow learner category [40]. The purpose of giving participants initials is intended to maintain privacy and protect information about the subject [41]. Participant profiles can be seen in table 1 .

Table 1. Participants Profile

\begin{tabular}{c|c|c|c|c}
\hline Intial & Position & Male & Age & Total \\
\hline M & Student & 1 & 14 & 1 \\
\hline
\end{tabular}

\subsection{Research Instruments and Procedures}

Before conducting the research, the first step conducted by the researcher was to ask permission for research at school and also ask the participants' permission to become the research subject. The design of this study uses procedures; 1) the researcher determines the subject;2) the researcher explains the ability to read the Qoran; 3) the researcher makes the first observation and the teacher who is appointed to conduct the Quran reading test; 4) the researcher determines the student's initial condition based on the test results A1; 5) the researcher asked the teacher to give the first student intervention on subject/B1;6) the researcher made a second observation 
when the test was repeated/A2; 7) the researcher conducted a third intervention through teacher/ B2; 8) the researcher carried out the third observation to see the latest condition of the students/ A3.

The instrument used in this study was an observation sheet in the form of a checklist of intervention results and also an interview protocol or guide. The checklist is used to determine students' abilities before and after obtaining research interventions. Meanwhile, the interview guide is used to gather information about the subject's condition from the aspects of personality and competence, and attitudes.

\subsection{Data analysis}

The research data analysis technique was conducted using descriptive statistical techniques which will provide an overview through graphs, tables, and others so that it is easier to understand [42]. The analysis procedure is carried out in three stages, namely reducing the data based on the research results, presenting the data, and analyzing it in a narrative form to provide an interpretation of the data that has been obtained.

\section{Results and Discussion}

Based on the results of data analysis, it was found that slow learner students had increased abilities in the aspects studied. Slow learner / slow learner students in this study will look at four aspects, namely about reading the Koran based on Makhorijul Huruf, Tajwid, Tartil and Tartib. The ability to read the Quran based on these four aspects, there are at least 2 aspects that can be mastered by students, namely aspects of the mahkrojul letter and tawjid. The results of preliminary observations or observations based on the reading test carried out found that students did not have this minimum ability so that it was necessary to give an intervention to improve their Quran reading ability. In the initial test, it was found that students had the Makhorijul Huruf ability of 30, the Tajwid ability of 30, the Tartil ability of 30, and the Tartib ability of 25 .

Based on the above conditions, the specially appointed teacher takes a reading test to determine the first baseline (Precondition). After that, they are asked to intervene or treat slow learner students how to read. The form of intervention carried out was that students were taught repeatedly about how to read the letter macros, tajwid, and tartil. The next stage after being given the treatment was observed by the researcher in the observation sheet. The second intervention is given back. The last one will be observed to be the final result of the student's postcondition. The difference in results between the pre-condition and post-condition can be seen in Figure 1.

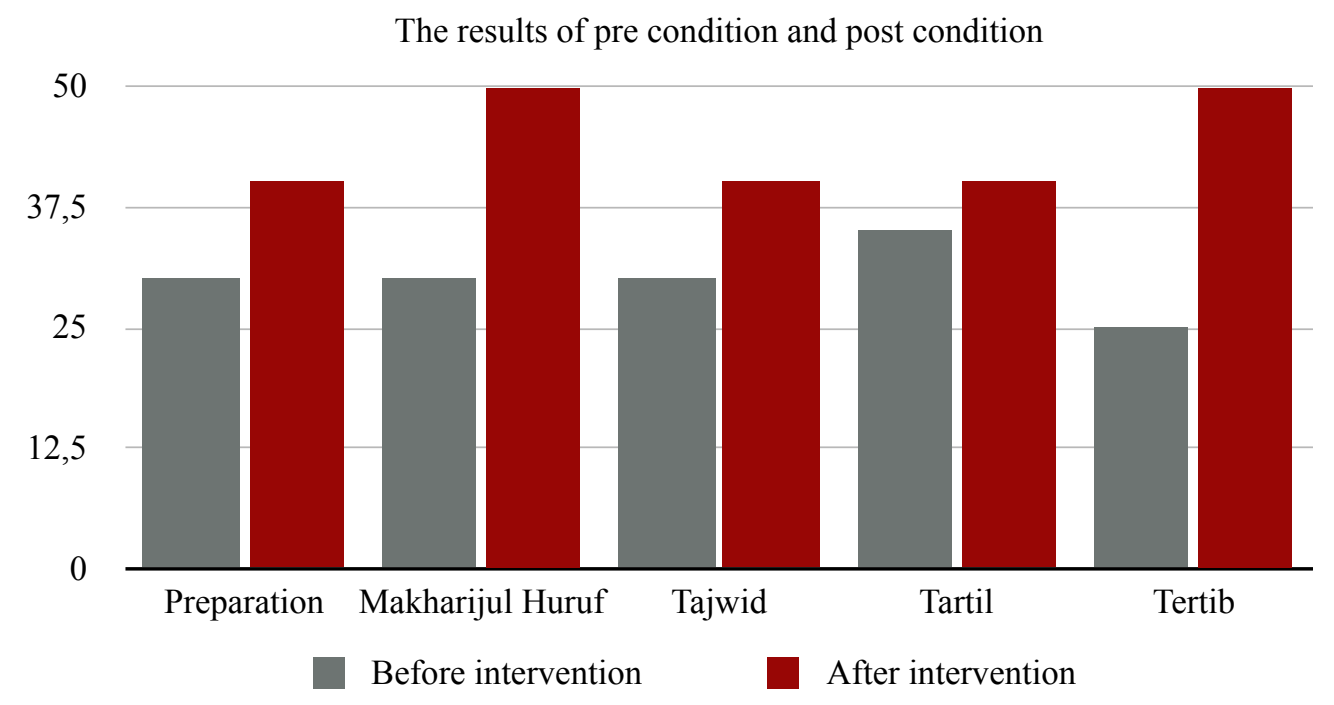

Fig. 1. The ability of Slow Learner students before and after the intervention

The results of students' abilities based on the data above indicate that there are differences in student abilities before and after the intervention. In the phase before the intervention was given, the 
students' ability to read al-Quran tests was the Makhorijul Huruf in number 30, Tajwid in number 30 , and Tartil at number 35, and Tartib in reading at number 25 . After the intervention was carried out there was an increase in the results, namely the student's ability to read the al-Quran is number 40, Tajwid in number 50, and Tartil at number 40, and Tartib read at number 50.

The results of further data show that direct treatment or a coaching system (mentoring one child) with the AIR method can improve students' abilities in reading the Quran. In interpreting the change in the panic in reading the Quran, slow learner students can do it based on the category of assessment as in table 2 .

Table 2. Rating Category

\begin{tabular}{c|cl}
\hline \multirow{2}{*}{ Number } & \multicolumn{2}{|c}{ Rating category } \\
\cline { 2 - 3 } & Range of Result & \multicolumn{1}{c}{ Asessment Criteria } \\
\hline 1 & $1-30$ & Not smooth \\
\hline 2 & $31-60$ & Somewhat smooth \\
\hline 3 & $61-90$ & Current \\
\hline 4 & $91-100$ & Very fluent \\
\hline
\end{tabular}

Observation sheets are also used to observe the development of students' abilities in reading the Koran from the initial conditions to the conditions after the intervention. In the observation sheet, each aspect will be seen based on before the intervention occurred and after the intervention was made. The observation results can be seen in Figure 2.

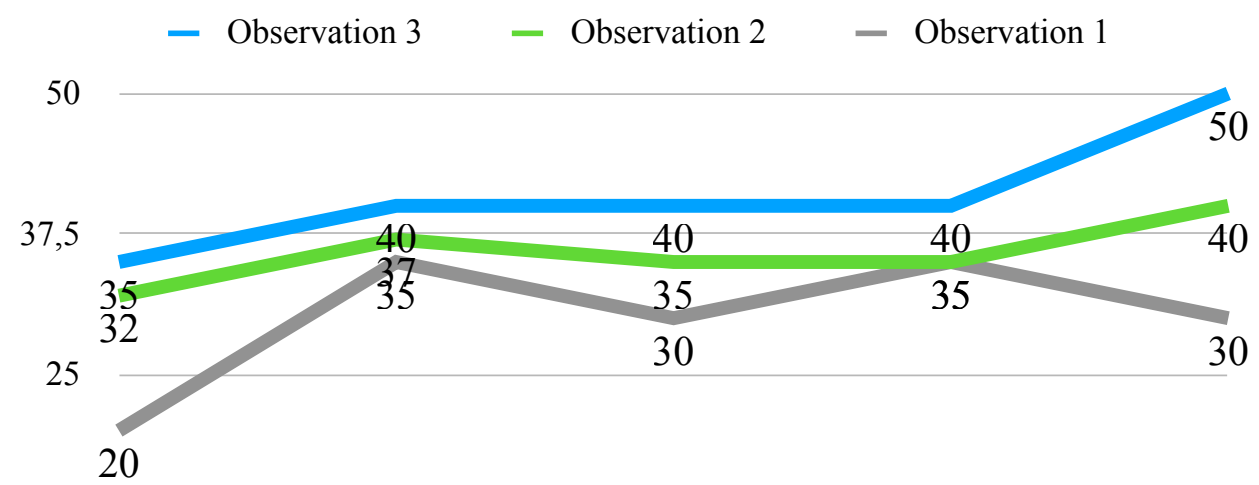

12,5

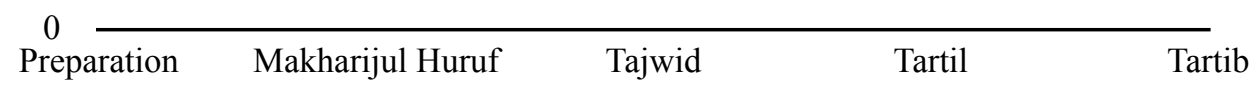

Fig. 2. Observation results in the ability to read the Holy Quran

Figure 2 shows that the reading ability of slow learner children has increased according to the aspects measured after the intervention. Student interviews were added to the data collection to reinforce the results of the assessment with the intervention. Regarding the benefits of this selflearning model, students said that "studying alone with the teacher makes it easier to read the Qoran. Not ashamed of friends ".

As for the weaknesses, students feel that "not all teachers want to guide them. And it took a long time to understand". Information from the interview results illustrates that there are still problems faced by slow learner children, one of which is the absence of a special companion teacher in 
teaching reading the Koran. Also, the need for a long time will interfere with the learning process in general for all students. Support within the family, especially from parents, also affects the increase in students' ability to read the Qoran. Repetitive activities at school and home will certainly make it easier for students to improve their abilities.

The results showed that the ability of students after receiving the intervention increased. But students' skills in reading the Qoran still need to be developed again. Even though they have been given repeated training and are continuously monitored the results are by observations, there are still several things that need to be addressed. The availability of teachers and special time in teaching reading skills for slow learner students needs to be considered [43]. Besides giving intensive motivation to students to keep learning also needs to be done continuously [44].

Learning models and strategies for improving reading the Qur'an are done using drills or given special and continuous training. Repetitive activities will improve students' understanding and skills [45]. The complex learning needs for slow learner students in education are certainly homework together. There are two important elements, especially in inclusive schools, that the ability of teachers is a major factor in the success of learning, especially religious learning. Teachers are required to master the required competencies such as pedagogical, professional, and other competencies [46]. Teacher competence regarding the theory and practice of learning for inclusive children needs to be improved in the form of continuous training. This means that competency training is given not only once or twice, but needs to be continuous and structured. Considering the demands for inclusive schools in every region, this is a big challenge for the world of education [47].

Looking at the results of analysis and observation, it can be found that the increase in the provision of interventions has shown an effect, although not too significant. This is because the provision of intervention may still be lacking. After all, it only intervened twice. More interventions will further improve the results. But this also has a relationship with the duration of time required. The more interventions and observations provided, the longer it will take.

The results of the interviews also reinforce the results that the use of interventions for students makes students interested and enthusiastic about learning. Even though teachers need more time and sacrifice time for other students.

Another thing that can be concluded from this research is that about the learning system in inclusive schools, in general, readiness is needed for schools to prepare all tools for learning, both related to curriculum, teaching teachers, and media that make learning easier. On the other hand, the need for comprehensive learning for inclusive schools is the importance of developing teacher competence in the form of continuous training. For this reason, no small amount of funding is required. Therefore schools must be ready and provide funds for the sake of the success of the educational goals that have been announced. But not all schools have readiness for implementation. Also, the condition of schools which usually do not have teachers who specifically handle children with special needs, especially slow learner children. This is one of the main obstacles.

Also, other factors can become obstacles, such as the emergence of students' lack of selfconfidence or insecurity, lack of motivation and support from parents, and the absence of assistance in parents, especially in providing education to read the Koran.

\section{Conclusion}

There are at least three conclusions obtained in this study. First, there is an increase in the ability of slow learner students in reading Quran after attending special training conducted by teachers by the areas being assessed, namely makhrojul letter, tawjid and tartil. Second, special learning for slow learner children with special coaching and drill methods has great benefits. Technically, it helps students in improving their ability to read the Quran. Third, collectively, the learning process for inclusive children, especially those in the slow learner category, needs more attention. Because they have abilities that are almost the same as normal children in terms of intelligence. only able to catch and understand is a little slow.

If the student's ability to read the Quran is expected to improve, it is necessary to do special, more intensive training with coaching and drill models and sufficient time so that the results 
obtained are more optimal. The results of this research can also be a recommendation for future studies that carry similar themes. Two things need to be considered based on the results of this study. First, the need for continuous training for teachers who specifically handle the learning of slow learner children. Second, it is necessary to develop other methods for a more diverse variety of learning. Many limitations are still experienced in this study. This research is still being carried out in a limited scope. Also, this type of research has not been explored and developed in more depth. This limitation can be followed up by subsequent studies that are stronger methodologically and increasingly from exploring the theme.

\section{References}

[1] Permendikbud, "Pembelajaran Pada Pendidikan Dasar Dan Pendidikan Menengah," Menteri Kesehat. Republik Indones. Peratur. Menteri Kesehat. Republik Indones., Vol. Nomor 65, No. 879, Hal. 2004-2006, 2015.

[2] H. C. A. Kistoro, C. Setiawan, E. Latipah, Dan H. Putranta, "Teacher"S Experiences In Character Education For Autistic Children In Indonesia," International J. Eval. Res. Educ., Vol. 10, No. 1, 2021.

[3] A. Azra, Pendidikan Islam Tradisi Dan Modernisasi Menuju Milenium Baru. Jakarta: Logos Wacana Ilmu, 2003.

[4] S. Syaiful, Konsep Dan Makna Pembelajaran. Bandung: Alfabeta, 2010.

[5] R. Undang-Undang, Tentang Sistem Pendidikan Nasional. Jakarta: Sinar Grafika, 2006.

[6] M. Bosra, H. C. A. Kistoro, Dan G. A. Syawaliani, "Model Of Teacher Communication In Learning Islamic Education In Autism Children," At Ta'lim, Vol. 27, No. 3, 2020.

[7] Jacob U'mofe Gordon, Ed., Bullying Prevention And Intervention At School, Integrating Theory And Research Into Best Practices. Gewerbestrasse: Springer Nature, 2018.

[8] S. Saridudin, "Pengembangan Kurikulum Pendidikan Diniyah Formal (Pdf) Di Pesantren Ulya Zainul Hasan Probolinggo," Edukasi J. Penelit. Pendidik. Agama Dan Keagamaan, 2020.

[9] Y. Masduki, H. C. Adi Kistoro, S. Ru'iya, S. Sutarman, Dan S. Sukirman, "Strengthening Religious Education For Family Resilience In Yogyakarta Muslim Minorities," Conciencia, Vol. 20, No. 1, Hal. 28-39, 2020.

[10] H. C. A. Kistoro, M. Zulvia, Dan A. F. Asyha, "Studi Kompetensi Guru Dan Linieritas Pendidikan Dalam Peningkatan Prestasi Belajar Siswa Di Sd Negeri 1 Gunung Tiga Dan Sd Negeri 1 Ngarip Lampung," Al-Tadzkiyyah J. Pendidik. Islam, Vol. 10, No. 2, Hal. 245-255, 2020.

[11] E. Latipah, H. C. A. Kistoro, Dan I. Khairunnisa, "Scientific Attitudes In Islamic Education Learning: Relationship And The Role Of Self-Efficacy And Social Support," Edukasia J. Penelit. Pendidik. Islam, Vol. 15, No. 1, Hal. 37, 2020.

[12] Mumpuniarti Mumpuniarti, "Pendidikan Anak Slow Learner.," J. Ilmu Kesehat. Aisyah, Vol. 1, 2016.

[13] M. Syah, Psikologi Islam Dengan Pendidikan Baru. Bandung: Pt. Remaja Rosdakarya, 2008.

[14] D. D. Ratri, Psikologi Anak Berkebutuhan Khusus. Yogyakarta: Psikosain, 2016.

[15] Purwaningtyas Maylina, "Strategi Pembelajaran Anak Lamban Belajar (Slow Learner) Di Sekolah Inklusi Sd Negeri Giwangan Yogyakarta," Universitas Negeri Yogyakarta, 2014.

[16] Sylvia Dian Wijaya Anna, "Layanan Akomodasi Guru Dalam Pembelajaran Untuk Siswa Lamban Belajar (Slow Learner) Di Kelas V Sd Negeri Tamansari I," Pendidik. Guru Sekol. Dasar Ed., Vol. 5, 2016.

[17] Y. Suciyanti Dan A. M. Nita, "Problematika Slow Learner," J. Pendidik. Guru Madrasah Ibtidaiyah, Vol. 1, No. 1, Hal. 12-25, 2018. 
[18] W. Amelia, "Karakteristik Dan Jenis Kesulitan Belajar Anak Slow Learner," J. Aisyah J. Ilmu Kesehat., Vol. 1, No. 2, Hal. 53-58, 2016.

[19] L. Maftuhatin, "Evaluasi Pembelajaran Anak Berkebutuhan Khusus (Abk) Di Kelas Inklusif Di Sd Plus Darul 'Ulum Jombang," J. Stud. Islam Univ. Pesantren Tinggi Darul 'Ulum Jombang, Vol. 6, 2014.

[20] F. Herlinda, "Meningkatkan Kemampuan Membaca Kata Melalui Media Audio Visual Bagi Anak Slow Learner," J. Ilm. Pendidik. Khusus, Vol. 3, No. 3, Hal. 53-63, 2014.

[21] D. Griffin, Slow Learners: A Break In The Circle - Practical Guide For Teachers In Secondary Schools. London: The Woburn Press, 2005.

[22] Moskowitz M., "Teaching The Slow Learner Author ( S ): Myron Moskowitz Published By The University Of Chicago Press Stable Url : Http://Www.Jstor.Org/Stable/1082853," The Unversity Of Chicago Journals, Vol. 56, No. 8, Hal. 476-483, 1948.

[23] L. V Stahlecker, "Motivating The Slow Learner To Read Motivating The Slow " Learner To Read," Vol. 46, No. 3, Hal. 78-82, 2020.

[24] N. H. Rofiah Dan I. Rofiana, "Penerapan Metode Pembelajaran Peserta Didik Slow Learner (Studi Kasus Di Sekolah Dasar Inklusi Wirosaban Yogyakarta) Nurul Hidayati Rofiah,” J. Kaji. Penelit. Pendidik. Dan Pembelajaran 2, Vol. 2, No. 1, Hal. 94-107, 2017.

[25] B. Baharudin, Pendidikan Psikologi Perkembangan. Yogyakarta: Ar- Ruzz Media, 2012.

[26] M. Muhaimin, Paradigma Pendidikan Islam. Bandung: Pt. Remaja Rosdakarya, 2012.

[27] A. S. Dan W. Widiastuti, "Multicultural Education Model In Traditional Pesantren In Tasikmalaya To Prevent The Threat Of Radicalism," Ilmu-Ilmu Sos. Dan Hum., 2018.

[28] A. Humam, Cara Belajar Membaca AlQuran. Jakarta, 2000.

[29] Ash Shabuni. Moh Ali, Rawai'ul Bayan (Terj.), Tafsir Ayat Al-Ahkam Al-Quran. Surabaya: Bina Islam, 1987.

[30] A. Mustafa Al Maraghi, Tafsir Al Maraghi, 3 Ed. .

[31] G. Singh, "Effectiveness Of Individualized Education Program For Slow Learners.," Indian J. Pediatr., Vol. 73, No. 11, Hal. 135-137, 2006.

[32] K. J. Vannest Dan J. Ninci, "Evaluating Intervention Effects In Single-Case Research Designs," J. Couns. Dev., Vol. 93, No. 4, Hal. 403-411, 2015.

[33] Sumarni, Sugiarto, Dan Sunarmi, "Implemetasi Pembelajaran Auditory Intellectualy Repetition (Air) Terhadap Kmampuan Berpikir Kritis Dan Disposisi Matematis Peserta Didik Pada Materi Kubus Dan Balok,” Unnes J. Math. Educ., Vol. 5, 2016.

[34] R. H. Horner Dan S. L. Odom, "Designs : Logic And Options," Hal. 27-51, 2014.

[35] D. Martens, Research And Evaluation In Educational And Psychology 4th. United States: Sage Publications, 2015.

[36] T. R. Kratochwill Et Al., Single-Case Designs Technical Documentation. 2010.

[37] T. R. Kratochwill Et Al., "Single-Case Intervention Research Design Standards," 2013.

[38] Suyatno, Menjelajah Pembelajaran Inovatif. Surabaya: Masmedia Buana Pustaka, 2009.

[39] A. Maulana, "Model Pembelajaran Air Untuk Meningkatkan Kemam- Puan Komunikasi Matematika Siswae," F Mipa Upi, 2012.

[40] J. W. Creswell, Qualitative Inquiry \& Research Design, Choosing Among Five Approaches, Vol. 2nd Ed. 2007. 
[41] Clark Moustakas, Phenomenological Research Methods, 1 Ed. California: Sage Publications, 1994.

[42] B. Nurgiyantoro, G. Gunawan, Dan M. Marzuki, Statistik Terapan Untuk Penelitian Ilmu Sosial. Yogyakarta: Gadjah Mada University Press, 2017.

[43] Lumaurridlo, H. Retnawati, H. C. A. Kistoro, Dan H. Putranta, "School Readiness Assessment: Study Of Early Childhood Education Experience," Elem. Educ. Online, Vol. 20, No. 1, Hal. 468-478, 2021.

[44] H. C. A. Kistoro, "Perbedaan Tingkat Agresivitas Pada Siswa Smu Muhi Yogyakarta Berdasar Pola Asuh Dan Jenis Pekerjaan Orang Tua," Al Misbah, Vol. 1, No. 1, 2013.

[45] E. Latipah, "Pengaruh Strategi Experiential Learning Terhadap Self Regulated Learning Mahasiswa," Humanitas (Monterey. N. L)., Vol. 14, No. 1, Hal. 41, 2017.

[46] R. I. Kementerian Pendidikan Dan Kebudayaan, "Permendikbud No14 Tahun 2017," 2017.

[47] M. Oey-Gardiner Et Al., Era Disrupsi: Peluang Dan Tantangan Pendidikan Tinggi Indonesia. 2017. 